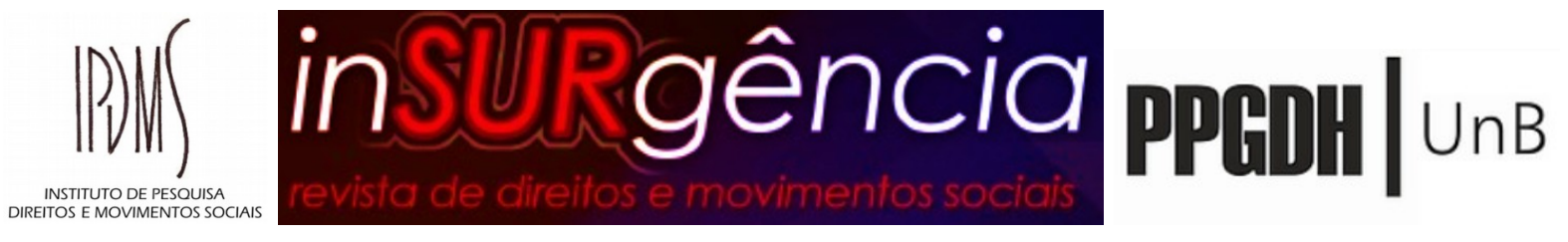

\title{
Entrevista com Guilherme Boulos ${ }^{1}$, realizada e degravada por Henrique
}

\section{Botelho Frota ${ }^{2}$ João Aparecido Bazzoli ${ }^{3}$ e André Felipe Soares Arruda ${ }^{4}$, no dia 29 de junho de 2020}

$(\mathrm{cc}) \mathrm{EY}$ This work is licensed under a Creative Commons Attribution 4.0 International License.

Henrique Frota, João Bazolli, André Arruda: Oi Boulos. Inicialmente gostaríamos de te agradecer pela possibilidade de conceder a entrevista. Vamos te jogando algumas perguntas, mas se trata de uma conversa tranquila sobre a política fundiária e a produção das cidades aqui no Brasil e na América Latina. Vamos fazer uma coisa mais livre. Nós separamos três blocos grandes de questões pra ir colocando pra você.

Um primeiro bloco: como você enxerga historicamente que a estrutura fundiária no Brasil tem moldado, tem delimitado a maneira como as cidades se constituíram.

Um segundo é pra gente mergulhar nos quatro últimos anos da realidade brasileira: desde que aconteceu o golpe de 2016 pra cá e todas as mudanças que aconteceram do ponto de vista legislativo, nova lei de regulação fundiária no campo e na cidade. Tudo isso, e como você tá enxergando.

E um terceiro bloco pra gente conversar como os movimentos populares, em particular o MTST, tem proposto alternativas de ruptura com estes modelos de propriedade individual de gestão individual produção habitacional via mercado.

Vamos começar por esta primeira parte, de que maneira você analisa, e aí o próprio MTST, como as cidades brasileiras historicamente se constituíram e que relação você vê disso com a estrutura fundiária que nosso pais foi delimitando no nosso sistema jurídico.

1 Membro da coordenação nacional do Movimento dos Trabalhadores Sem-Teto (MTST) e membro do Diretório Nacional do Partido Socialismo e Liberdade (PSOL).

2 Graduado em Direito pela Universidade Federal do Ceará. Mestre pelo Programa Regional de Pós-Graduação em Desenvolvimento e Meio Ambiente (PRODEMA) da Universidade Federal do Ceará. Mestre em Direito Urbanístico pela Pontifícia Universidade Católica de São Paulo. Contato: henriquebfrota@yahoo.com.br 3 Professor na Universidade Federal do Tocantins (UFT) do Curso de Direito. Docente Permanente do Programa de Pós-graduação em Desenvolvimento Regional (PPGDR/UFT). Pós-doutoramento pela Universidade de Lisboa Contato: jbazolli@gmail.com

4 Doutor em Direito das Relações Sociais (Direitos Difusos e Coletivos) pela PUC/SP Pontifícia Universidade Católica de São Paulo (2017). Mestre em Direitos Difusos e Coletivos pela UNIMES/SANTOS Universidade Metropolitana de Santos (2010). Especialista em Direito do Consumidor pela ESA-OAB/SP Escola Superior de Advocacia da Ordem dos Advogados do Brasil - Secção de São Paulo (2008). Graduação em Direito pela Faculdade de Direito de São Bernardo do Campo (2004). Professor do Curso de Pós-Graduação Stricto Sensu da Faculdade de Direito da Universidade Federal de Goiás - Regional Goiânia - Mestrado em Direito Agrário. Contato: andrefsarruda@gmail.com 


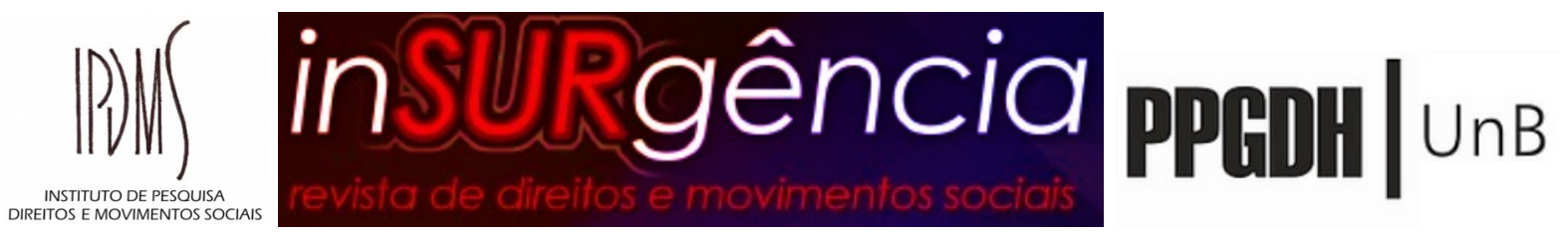

Guilherme Boulos - Bom nesse ponto o marco foi a Lei de Terras de 1850, ali se começa a considerar de maneira jurídica a terra como mercadoria, e é importante, porque toda vez que se discute propriedade fundiária, posse e legitimidade das ocupações, sempre vem o argumento meritocrático de dizer que quem tem a terra, trabalhou pra ter a terra, quem tem a terra, o seu ancestral trabalhou pra ter a terra, e a lei de terras de 1850 desmente tudo isso, a lei de terras de 1850 legitimou uma propriedade da terra baseada em grilagem, em compadrio, e entrega pela Coroa na época, quer dizer o Império determinava seus escolhidos e entregava a propriedade, tornando, constituindo no Brasil a propriedade privada da terra. Ela foi feita por influência política, por patrimonialismo, jamais pelo mérito. Se não vai encontrar naquele momento qualquer um que tenha trabalhado, e a partir do seu trabalho adquiriu as condições de ter a terra. Então, se tem um pecado original na constituição fundiária brasileira que tá baseado, e que a Lei de terras de 1850 legitima.

Muito bem, ali naquele momento a gente ainda não tinha propriamente uma dinâmica urbana estabelecida no Brasil, depois com a abolição inacabada da escravidão, com a proclamação da República, nós tivemos trabalhadores libertos que foram indo para as cidades, se constituíram moradias absolutamente precárias, naquele momento se tinha uma hegemonia de cortiços, de uma moradia precária de aluguel, aqui nós estamos falando do início do século XX, e essa dinâmica permanece durante toda a República Velha.

O tipo de cidade que a gente tem hoje começa a surgir depois da revolução de (19)30, então depois da revolução de (19)30 se tem um surto industrializante no Brasil, nos anos (19)40 e tal, na era Vargas, você tem um processo de urbanização já motivado pelo êxodo rural e isso começa a constituir grandes aglomerados urbanos no país nas décadas seguintes. Aí você começa a ter uma operação de uma dinâmica mais propriamente imobiliária, da forma como a gente conhece hoje, que foi baseada, sobretudo, num processo de segregação urbana.

Então, o que é que houve, aliás eu estava estudando isso nestes dias por causa do coronavírus, o quanto as epidemias da época, isso desde o fim do século XIX, foram utilizadas como pretexto para segregação, né. O bairro Higienópolis em SP tem esse nome não por acaso, ele foi fruto de uma ação higienista, contra epidemias de febre amarela no circuito ali da estação da Luz que fazia a relação do café com o porto de Santos, e o circuito econômico de São Paulo estava ali, e ali também estavam os barões do café, então os barões do café foram pra 


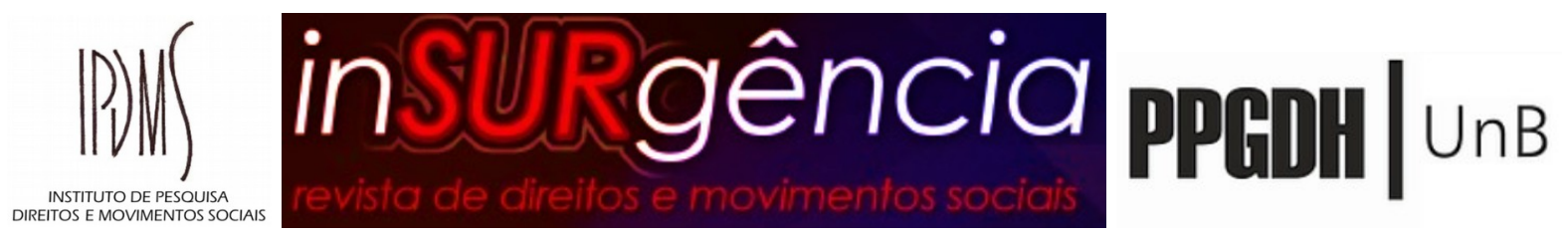

Campos Elíseos e fundaram Higienópolis, que era o bairro higienizado, o bairro onde não tinham habitações sujas, habitações que eram focos de contágio, que eram os cortiços.

Se começa a ter uma segregação (urbana) motivada por razões sanitárias, no Rio isso foi ainda mais evidente, com Barata Ribeiro ainda no sec. XIX, com Pereira Passos no início do século XX, baseado nos projetos do Haussmann em Paris, projetos de um outro modelo de cidades. Alargar avenida, acabar com os cortiços, e ai começam os mais pobres a subirem os morros, nessa época no Rio, e em São Paulo, como a geografia é outra, ninguém subiu o morro, as pessoas foram atiradas para as periferias, e esse processo ganha uma dinâmica brutal a partir da industrialização.

Que ai se tem uma operação, onde a especulação imobiliária, numa única operação tem três tipos de ganho. Primeiro ganho: ao tirar os cortiços e as habitações precárias dos centros, eles fizeram um processo de higienização, de gentrificação dos centros, e tornaram os centros valorizados imobiliariamente. Segundo ganho: eles, ao jogarem os trabalhadores mais pobres, os ex-escravos, os descendentes dos escravos, ao jogarem pros fundões das periferias eles ainda venderam os loteamentos, é o que o (Lúcio) Kowarick chamou de modelo periférico, de jogar pros fundões e ainda lotear clandestinamente e vender estes loteamentos. O terceiro ganho: foi o das áreas intermediárias, que é você, entre os novos loteamentos e o centro existente, você deixa grandes vazios urbanos e se aproveitava de todas as infraestruturas que iam para os novos loteamentos, porque elas tinham que passar por estes centros (e pelos vazios), estrada, linha de ônibus, rede elétrica, rede de água e ai você valorizava com essas melhorias públicas essas zonas intermediárias que depois eram vendidas para um outro setor social, pra profissionais, enfim, pra nascente classe média.

Então essa dinâmica já no início da cidade, e aqui falando propriamente de São Paulo, o que nós temos é o processo de expansão urbana e também um processo de expulsão urbana, essa característica ela depois é marcante de um modelo de cidade, ela é marcante de todos os ciclos de expansão no pais, inclusive dos últimos ciclos. Dos ciclos de especulação imobiliária mais recente, e ai já com outros atores, fundos imobiliários, financeirização da terra. Você muda os atores, você muda os formatos, mas você tem também, você não muda a lógica de jogar os mais pobres pra regiões mais distantes, mais periféricas, e criar um processo de inflação da terra urbana, nos últimos ciclos motivado pelo aumento do aluguel, que foi o principal gatilho de expulsão dos mais pobres que não podiam pagar mais o aluguel em regiões onde chegavam melhorias públicas ou investimentos privados a partir do surto imobiliário do século XXI, já 


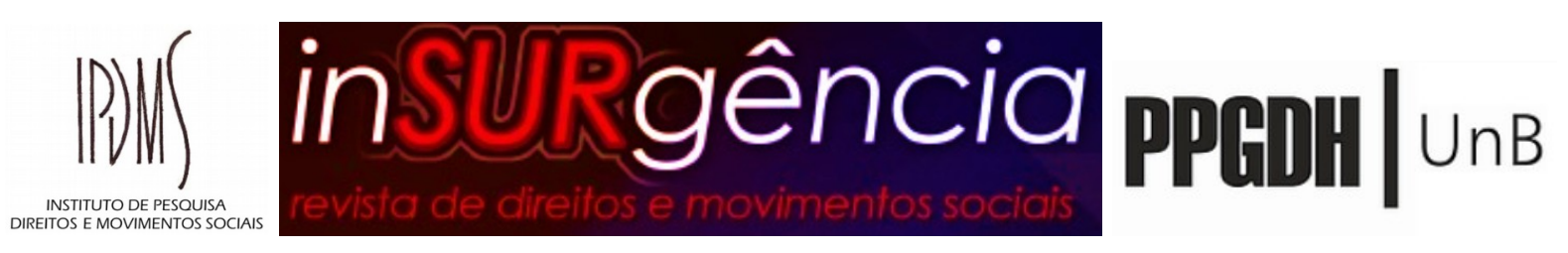

no governo Lula, mas isso pra dizer que tem uma lógica, um DNA nas nossas cidades, que está marcado por uma lógica excludente, está marcado por um protagonismo da especulação imobiliária, dos agentes imobiliários, e por um completo descaso pelos mais pobres que eram sempre jogados e atirados para as regiões mais distantes.

Henrique Frota, João Bazolli, André Arruda: Você acha que essa lógica, Guilherme, que de alguma maneira também e ao longo do século $X X$ nesse processo que você nos relatou, especialmente durante a ditadura militar, BNH (Banco Nacional de Habitação), foram feitas campanhas massivas da história da casa própria, de tornar-se proprietário do sonho brasileiro, da casa própria via propriedade, você entende também que, de certa forma, nossa população, inclusive essa periférica, essa população que foi jogada para as bordas da cidade, que ela assimila também uma ideologia proprietária a partir dessa estrutura

Guilherme Boulos - Não tenho a menor dúvida disso, essa inclusive é uma das dificuldades que a gente tem no próprio movimento social de luta por moradia, o quanto isso está enraizado socialmente, mas eu acho que tem dois aspectos que a gente precisa considerar aqui, o primeiro é esse aspecto mencionado na origem do BNH que é o aspecto histórico, eu me lembro que estava lendo um livro sobre o BNH há alguns anos atrás, que tinha assim a carta de intenções, de fundação do BNH, foi logo depois do golpe, o BNH foi fundado poucas semanas depois do golpe militar de (19)6. Qual era, o que que eles colocavam como objetivo: transformar o trabalhador em proprietário. Então isso tinha a ideia de curar a ferida nacional do golpe de (19)64, porque uma parte da classe trabalhadora apoiava o Jango, o Jango vinha com um projeto de reforma de base, o golpe foi dado contra essa classe trabalhadora, pra impedir o avanço de direitos e de reformas estruturais propostas pelo Jango, e agora precisava pra ditadura ter governabilidade social, ela precisava repactuar com essa parcela dos trabalhadores, e ai o BNH foi um instrumento pra isso. Se o trabalhador se considera proprietário, ele tem algo a perder, não é só as suas correntes como dizia o Marx, então esse trabalhador não vai para o enfrentamento e para a subversão, não vai se organizar para derrubar o regime, então tinha uma lógica disso no BNH que era evidente. Bom se o BNH entregou o peixe depois é outra história, a gente sabe que não entregou, sobretudo para os trabalhadores mais pobres. O BNH foi voltado, na sua lógica bancária, financeira, para as classes médias. Toda vez que o BNH tentou atender os mais pobres, com as COHAB’s, 


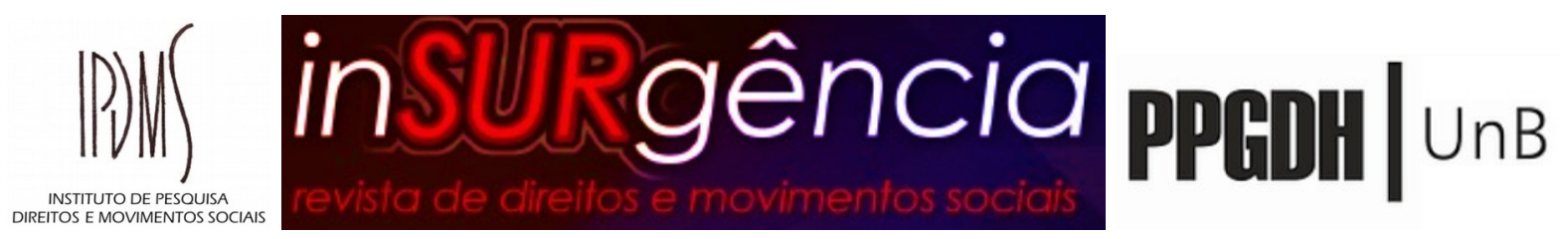

desfavelização, ele fracassou, e depois a implosão financeira do BNH nos anos (19)80 tem a ver com isso também, a lógica do BNH não parava em pé, porque ele tinha, de um lado, uma ambição declarada de atender os mais pobres, e de outro ele tinha um modelo financeirizado que excluía quem não era sujeito de crédito, ou seja, 80\%, 90\% do déficit habitacional brasileiro.

Mas a lógica da propriedade estava aí, e ela foi sendo enraizada, e ela vai ganhando gerações ao longo do Brasil, e todo mundo, inclusive o trabalhador mais ferrado, quer ser proprietário, ele quer ter a casa própria. E veja, tem gente que pode achar que isso é natural, não! Se pega em Paris, 2/3 das habitações de Paris são de aluguel, em outros lugares, outras culturas não é a casa o ideal de ter moradia. Os projetos de locação social mundo afora, ou seja, não é o único modelo possível, mas aqui no Brasil ele foi muito naturalizado.

Ele foi muito naturalizado, e esse é o aspecto que eu quero tocar, não só por uma razão ideológica, ele também foi naturalizado pela situação de precariedade dos trabalhadores do Brasil, porque ter a casa própria funciona, historicamente pra classe trabalhadora, como uma espécie de poupança. Aqui a gente tem uma rotatividade no trabalho tremenda, aqui a gente tem uma ameaça permanente do desemprego, crises cíclicas, recessões cíclicas. A história brasileira para os mais pobres é muito cruel. O cara ter uma casa não é simplesmente o deleitar-se, eu sou o proprietário, o cara ter uma casa é ele poder vender essa casa se ele tiver passando fome. A casa tem um aspecto de poupança num país onde a previdência, agora ainda menos, mas historicamente não teve cobertura universal. Num país onde os direitos trabalhistas, uma parte importante dos trabalhadores, estiveram à margem dos direitos trabalhistas por serem precários, por serem informais. Então a casa própria era uma espécie de garantia, de poupança que o cara não ia passar fome. Isso é assim até hoje. Porque tantas histórias do cara que ganha a casa num programa social e vende, é fácil atribuir isso só a malandragem, é malandro, não precisava. Não! As vezes o cara vai lá, ganha a casa, começa a passar fome dentro do apartamento que ele recebe, e ele vende e volta a morar na favela pra poder comer durante alguns anos. Sabe, então acho que a gente tem que tomar algum cuidado em demonizar o culto à casa própria, porque se a gente for ver no chão da sociedade, ele tá relacionado a uma estratégia de sobrevivência, não na questão simplesmente ideológica de eu quero ter a minha casa. Como que a gente pode lidar com isso? Aí é um outro capítulo da coisa. Acho que não é papel dos movimentos sociais, de quem luta pelo direito à cidade incentivar o culto à casa própria, nosso papel é pensar formar alternativas de propriedade. 


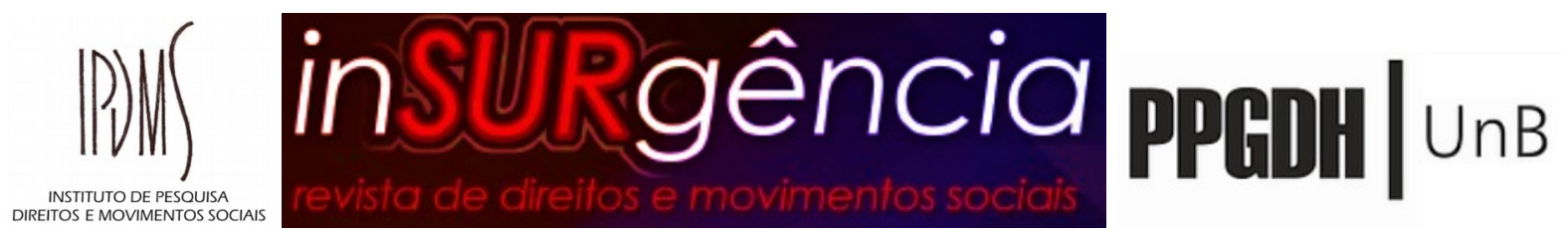

Como foram construídas as FUCVAM no Uruguai? Que eu acho um grande exemplo. Que construiu formas alternativas de propriedade. Eu acompanhei um esforço tremendo, ainda no governo Evo Morales, na Bolívia, de garantia das constituintes bolivianas da propriedade coletiva da terra. Você tem debates na Argentina com movimento de ocupantes e inquilinos. Você tem em várias partes discussões de outras formas de propriedade. Discussão de modelos de locação social como política habitacional prioritária. Nós temos que investir nisso, mas com muito cuidado pra não desmoralizar o que é pra o povo uma estratégia de sobrevivência. Às vezes é fácil, do nosso lugar, como quem tem a questão da moradia bem assentada, como quem tem algum emprego fixo, como estudiosos da causa, a gente desmoralizar algo que para as pessoas é uma forma de sobreviver.

Henrique Frota, João Bazolli, André Arruda: Isso que você coloca muito bem, no contexto de que, a estrutura fundiária e a maneira como a classe trabalhadora ou a população excluída se posiciona neste contexto, não pode ser desconsiderado também qual é a nossa estrutura econômica e como que essas pessoas se viram pra sobreviver. Então quando você diz que a casa própria acaba sendo poupança popular, de fato é ali a maneira como as pessoas encontram de alguma maneira estabelecer um patamar mínimo de garantia de um futuro, que é sempre incerto. Pra essa população é sempre incerto. E ai você entra nestas experiências latinoamericanas, e você já fez vários cursos, e já apresentou também várias situações, modelos de gestões, inclusive aqui no Brasil, onde não rompemos com uma estrutura fundiária, que são essas que você estava relatando, mas os movimentos populares organizados no Brasil desenvolveram experiências, pelo menos, de uma gestão melhor, mais coletiva, democrática de empreendimentos habitacionais, inclusive nesse ciclo mais recente do Programa Minha Casa Minha Vida. Queria que você falasse um pouco como que você vê, inclusive, o Programa Minha Casa Minha Vida como um desenho macro específico, e ai quando ele abre uma linha que é o MCMV entidades, isso é uma brecha de ruptura? Como que você enxergou o que aconteceu com o MCMV entidades?

Guilherme Boulos - O MCMV tem que ser entendido em suas origens. Por que que o Lula só vai criar um programa de habitação no penúltimo ano de seu governo? Seu segundo mandato. Porque ele escolheu determinadas prioridades de governo, e até aquele momento a moradia popular não estava entre elas. Estava o combate à fome, estava a inclusão dos mais pobres no 


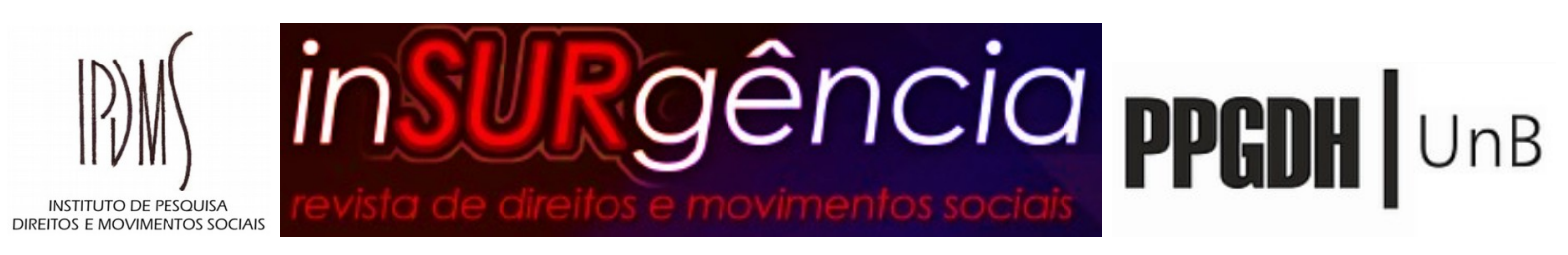

ensino superior, estavam, enfim, outras políticas também de muita legitimidade e importância no país, mas o que gerou a necessidade de um programa como aquele, foi sobretudo a crise de 2008. A explosão da crise de 2008 gera, vamos lembrar que ela explodiu no setor imobiliário, no sub-prime norte-americano, e aqui se você olhar, as grandes construtoras brasileiras estão todas com capital aberto na bolsa e internacionalizadas. Aquela crise teve um efeito de contágio. Os papeis podres estavam em todo lugar, tanto que gerou a falência de grandes bancos como o Lehman Brothers, chegou na GM (General Motors), porque no sistema financeiro é isso, ele é apátrida e os papeis circulam. Então, o que que houve, que me parece que havia um risco de falência de empresas do setor da construção no Brasil, construção civil e construção pesada. Ao mesmo tempo existia um risco geral, pelo efeito de contágio da economia internacional, da economia brasileira ir pra lona, onde ela estava num bom momento. Qual a estratégia que o governo desenha naquele momento? Vamos fazer políticas anticíclicas. Vamos botar dinheiro público na veia pra poder gerar emprego, e evitar um contágio mais forte da crise no Brasil. Qual é o setor da economia com maior capacidade de geração orgânica de emprego rápido? Construção civil. Então, naquele momento, o PAC cumpre o papel da construção pesada e o MCMV cumpre o papel da civil. Você gera milhões de empregos com estes programas. Então, tinha um efeito econômico, e mais, ai pra mim é o ponto do problema. Você tinha que salvar as empresas da construção com risco de falência em série. Então você cria um programa que foi feito sob medida pro setor da construção, pra um setor privado. E ai é o problema da lógica do MCMV, senão a gente concebe que era um negócio só privatista, eram pessoas mal intencionadas. Não! Era uma lógica de salvar o setor da construção. Então, se a gente olhar a modulação do MCMV, ele não foi pensado a partir da perspectiva de um outro modelo de cidade, de resolver o problema habitacional do Brasil. Não! Esse foi o gancho. Ele foi pensado como efeito sobretudo econômico. Você pega o plano nacional de habitação, que na época estava sendo coordenado pelo Nabil, que fez audiências públicas pelo Brasil inteiro, foi ignorado, colocado dentro da gaveta, e vem um negócio de cima, do Ministério da Fazenda, com (Ministério do) Planejamento, com não sei o que, e falou “o programa é esse”. Eu me lembro na época, o movimento tinha pressionado, feito pressão, negociação com o governo federal. A gente negociava com a Inês Magalhães, que era secretária nacional de habitação, e a Inês recebeu o programa pronto. Certo! Isso fez com que o MCMV tivesse muitos vícios. O protagonismo do setor privado. Quem escolhe a localização dos empreendimentos? Não é o setor público, é o setor privado. O setor privado 


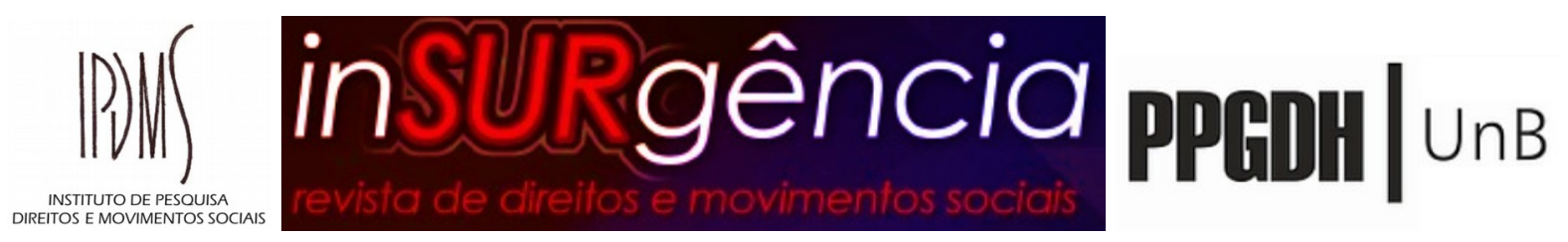

escolhe essa localização na lógica da lucratividade, então ele escolhe as regiões mais distantes, ganhando sobrelucro em terrenos que não são valorizados. Quem escolhe o projeto arquitetônico do empreendimento? O setor privado. A Caixa só estabelece padrões mínimos e aprova. Quem escolhe o tamanho do empreendimento? O setor privado. A Caixa só estabelece um padrão mínimo. Então, deixar todo o processo na mão do setor privado, da localização à concepção do padrão urbanístico e a qualidade e tamanho das habitações, é uma loucura. Dá no que deu. Construir aptos de $39 \mathrm{~m} 2$, caixinhas de fósforo, no fundão das cidades, onde não tem mais nada. Vamos dizer que a lógica do MCMV faixa 1 foi essa, e que contribui para o processo de segregação urbana. Porque muitas vezes, quando o MCMV foi usado como ferramenta de remoção, ou de regularização, ele tirou pessoas que moravam em lugares melhores pra jogar pra lugares piores. Então, esses são vícios e problemas do MCMV.

Óbvio que não foram só vícios, MCMV teve uma virtude, muito importante, que é preciso ser reconhecida, que se chama subsídio. Não existe possibilidade de você fazer um programa popular de habitação no Brasil, sem subsídio grosso, na veia, e o MCMV faixa 1 fez isso, até 95\% de subsidio. Ou seja, o cara não precisava pagar. Fundo garantidor, você não precisava comprovar nada, podia ter nome sujo que você entrava no empreendimento. Podia ter renda zero, desempregado, que você entrava no empreendimento. Isso não é qualquer coisa, isso é inédito na história brasileira. Então, isso é relevante, né! O modelo estava errado, o modelo foi concebido para as construtoras, mas o padrão de financiamento da faixa 1 é um legado, porque foi baseado num subsídio.

A história do MCMV entidades, os movimentos também quiseram e falaram "a gente ficou a vida toda aqui lutando por reforma urbana, lutando por moradia popular, vocês vão lançar um negócio desses só para as construtoras, e aí? E todo o acúmulo de debate de direito às cidades?” E aí chega o MCMV entidades. Então quer dizer, foi uma compensação, e uma compensação pequena. 2\%, eu não tenho os dados finais e atualizados, mas não é mais que isso dos empreendimentos produzidos pelo programa. É muito pouco, mas ali no MCMV entidades, embora ele ainda esteja marcado pelas travas burocráticas e as dificuldades do MCMV, ele aponta para um modelo muito interessante, que é o da gestão direta dos futuros moradores organizados e movimento social gerindo o processo, desde o projeto, localização, até a obra. Ele aponta para uma comparação que é extraordinária, que é você ver com o mesmo dinheiro o que o MCMV entidades fez e o que FAR-Empreiteiras fez. Nós temos vários exemplos. O MTST, nós fizemos, aqui perto da minha casa em Taboão da Serra (SP), 


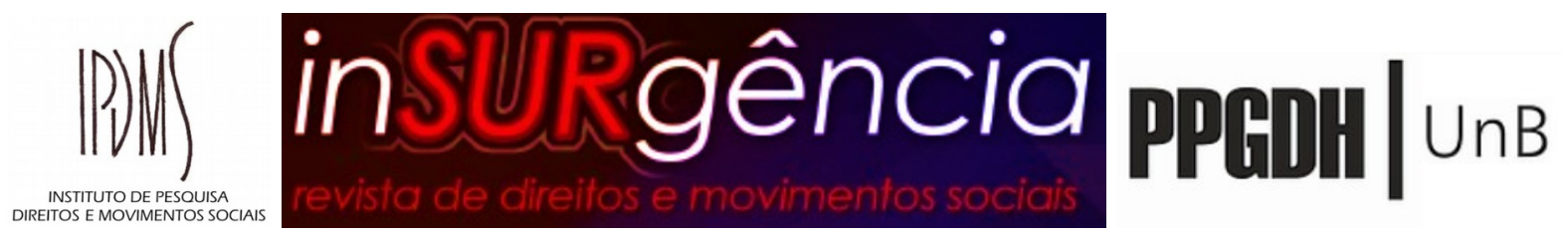

nós fizemos o maior apartamento faixa 1 do Brasil, gerido pelo MTST, Condomínio João Candido, que tá lá pra quem quiser ver. João Cândido A e B, cada um com 192 aptos, 384 aptos; aptos de 63 m2, com 03 dormitórios; prédios com elevador. Foi pioneiro da faixa 01. Área social de convivência e varanda em todos os apartamentos. Lá do lado, há 200 metros tem um MCMV PAR. 39 m2, sem área social, elevador nem se fala e varanda muito menos. Então, veja que loucura. O mesmo dinheiro. O mesmo dinheiro que a entidade geriu pra fazer $63 \mathrm{~m}^{2}$ a empreiteira geriu pra fazer $39 \mathrm{~m}^{2}$. Essa é uma comparação de modelo que o MCMV permitiu. Então, nós entregamos em Santo André (SP) 910 aptos no ano passado, com o mesmo perfil, era um pouco menor, $57 \mathrm{~m}^{2}, 56 \mathrm{~m}^{2}$, mas também varanda, elevador, área de convivência, churrasqueira. Ou seja, não estou dizendo que é o ideal. Ainda tinha muitas travas, mas meu modelo ideal de gestão popular não é o MCMV entidades, mas eu acho que ele apontou pra este caminho. Ali pode-se fazer, sobretudo, pro efeito de exemplo. Sim! Os movimentos sociais organizados podem fazer. Sim! Os movimentos sociais organizados fazem melhor e entregam. Porque tinha esse culto de que, não, não entrega; dá o dinheiro na mão dos caras e vai dar errado isso ai. Vai ficar obra inacabada. Obra inacabada, ficou um monte de construtora que faliu, que desviou, que fez esquema. No MCMV entidades você tem ali uma demonstração, um efeito demonstração do que a gestão popular é possível, é capaz de fazer.

Henrique Frota, João Bazolli, André Arruda: Chegamos 2015, 2016, e entendemos que o golpe de 2016 foi sendo gestado. Ele não aconteceu do dia pra noite. Então assim, a presença de Joaquim Levy no governo Dilma já era uma tentativa, alguma coisa de evitar algo do gênero. Mesmo 2014 com a questão da Copa do Mundo a gente já vem percebendo, talvez, um recrudescimento em relação, inclusive, à moradia. Os movimentos populares se organizando, fazendo ocupações. Uma ocupação emblemática aqui em São Paulo foi a “Copa do Povo”. Depois, nessa era mais depois do golpe, talvez a mais emblemática que ficou conhecida nacionalmente, foi a Povo sem Medo em São Bernardo do Campo. Então queríamos te perguntar já sobre esta era pós-golpe, depois que a Dilma saiu do mandato, nós tivemos não só um grupo que reúne qualidades bastantes nefastas, porque conservador, ultra neoliberal, um monte de questões ai, e esse grupo emplacou, também, mudanças na legislação fundiária brasileira, que não foi, simplesmente, a urbana, né! A lei 13.465(2017) mexeu com a Amazônia legal, mexeu com terra rural, mexeu com toda a estrutura fundiária 


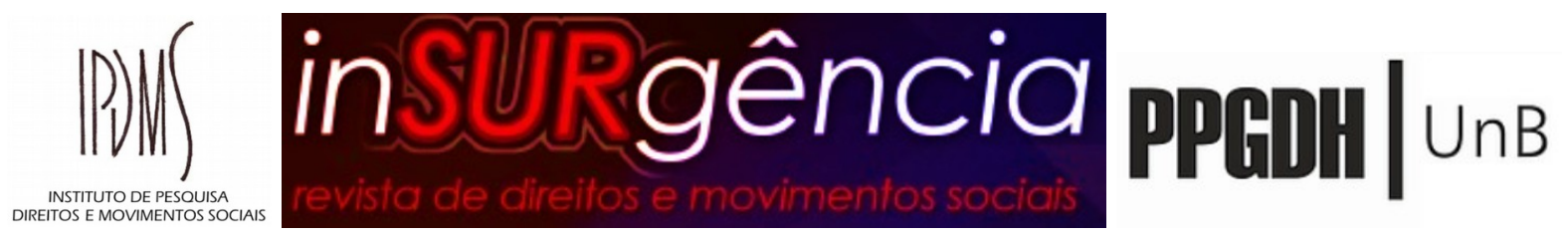

brasileira. Então queríamos te pedir pra fazer uma breve análise de como que você tem visto esses últimos 04 no Brasil em relação às lutas urbanas, especialmente a luta pela terra. E, nesse contexto, em relação a perseguição dos movimentos sociais, temos uma hipótese de que quando há uma mudança nos marcos normativos que procuram estabelecer a regulação fundiária, ou, enfim, regularizar a questão fundiária, parece que há um recrudescimento estatal em face dos movimentos sociais. Ai queríamos entender, e que você fizesse essa análise, se você tem essa percepção de que com os marcos normativos como a lei de registros de (19)73, a constituinte, o processo constituinte na década de (19)80, depois a primeira lei de regularização fundiária com o MCMV, e agora a de (13.465) de 2017. Você consegue fazer este paralelo? Tem este paralelo? A gente talvez consiga confirmar esta hipótese, de que durante a mudança destes marcos normativos, o pau cai pesado em cima dos movimentos sociais?

Guilherme Boulos - Vamos lá, vou começar com esta segunda questão. Sim! Esta hipótese para em pé, mas para em pé por um terceiro fator. Que a aprovação de marcos regulatórios mais favoráveis ao mercado, e antipopulares, ela sempre se dá em contexto de uma correlação de forças desfavorável pros mais pobres, e para os movimentos sociais. Então, o mesmo cenário que permite aprovar a lei de regulação fundiária do (Michel) Temer foi o cenário que permitiu o golpe de 2016, foi o cenário que criou condições pra ele fazer uma GLO em Brasília em dia de manifestação, ou seja, foi um cenário de liberação de pitbull. E ai, é claro, é o cenário que é o assassinato de indígenas, de quilombolas, aumenta a violência no campo, aumenta uma certa legitimação social da repressão a movimentos. Então, os marcos regulatórios reacionários e a criminalização e repressão dos movimentos sociais, tem a matriz comum de processos de avanço antipopular na história brasileira. É isso que eu enxergo. Por isso que eles tendem a coincidir ao longo da história.

Bom, os últimos anos, além de regularização fundiária, ele entregou pra essa turma. O governo Temer, de uma maneira mais global, foi um governo de pagar tributo, porque ele entrou lá de favor, né! Um cara que entra de favor precisa passar o governo pagando favor. Então, ele entrou a partir de uma adesão de bancadas de interesse ao seu governo. Eu me lembro de empresários disponibilizando jatinhos e helicópteros para os deputados irem pra Brasília votar pelo impeachment. Isso foi noticiado em grandes jornais. Ou seja, você tinha uma coalizão de interesses econômicos que sustentou o golpe de 2016, e a entrada do Temer. 


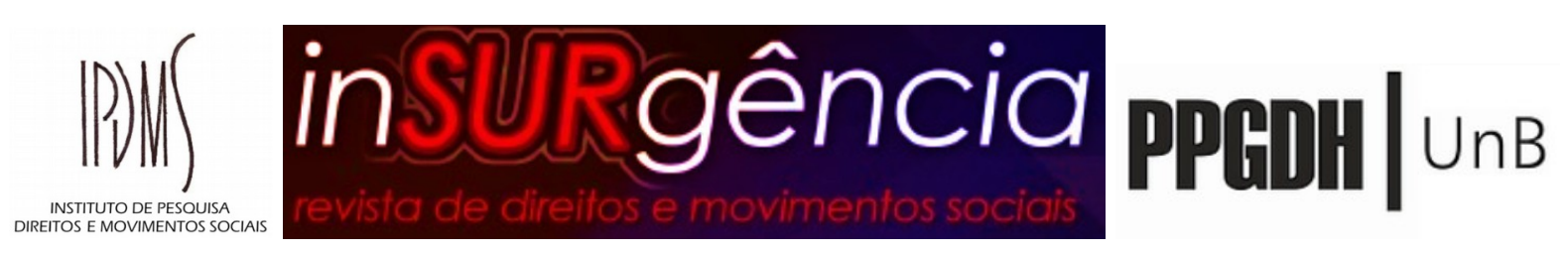

E o Temer, como não tinha apoio popular, que tinha zero de aprovação, acho que foi o governo menos popular da história brasileira, terminou o governo com 3\%, 2\% de apoio popular, uma coisa assim inacreditável. Em qualquer outro país era um governo que teria caído, né! Como ele não tinha apoio popular, a sustentação dele se dava exclusivamente pelo setor econômico e pelo parlamento, pra barrar as investigações contra ele. Então, o governo Temer era frágil neste ponto de vista. Ele tinha que ficar toda hora sendo uma espécie de operador direto desses interesses que sustentavam ele no poder. É nesse contexto que eu vejo a lei de regulação fundiária. Que foi um presente pra o agronegócio. Foi uma espécie de legitimação da grilagem. (A 13.465) foi concebida pela bancada ruralista pra poder legitimar o processo de grilagem, sob o pretexto de agilização. É verdade, a lei de regulação fundiária tinha vários problemas burocráticos que se expressavam, inclusive, na dificuldade de regularizar comunidade populares. Não podemos deixar de ver isso também. O pretexto utilizado pelo Temer tinha um fundo de verdade. Agora, o que valeu pra comunidades populares, para poder regularizar uma favela, valeu em dobro para o grileiro latifundiário que pode chegar lá e regulamentar a invasão de terra indígena, ou o que quer que seja, a história da Amazônia legal já mencionada, foi um contexto de abrir porteira.

A gente não viu isso só nessa área. O governo Temer fez isso em todas as áreas. Ele botou lobistas do setor privado como ministros, ou em altos cargos da República, pra ser o governo de prestar o serviço. O que não tinha passado por algum tipo de resistência nos treze anos de governo do PT, estava treze anos atrasado, naqueles dois anos liberaram geral. Não é? Seja em relação com a regulamentação financeira com o (Henrique) Meireles na Fazenda; seja em relação a questão da saúde com a desregulamentação de qualquer fiscalização dos planos de saúde com o Ricardo Barros, lobista de plano de saúde no Ministério da Saúde; com o Mendoncinha (Mendonça Filho) na Educação; e na regularização fundiária, não me lembro se foi o Bruno Araújo, ou se já foi o (Alexandre) Baldy; mas no Ministério das Cidades, com o Silvio Figueiredo, que eu acho que foi ali, quem ficou por trás da coisa toda, e que acabou fazendo.

Mas enfim, eu vejo de um contexto mais geral, né! E que evidentemente traz prejuízos, e agora, com o bolsonarismo, depois do Bolsonaro ganhando a eleição de (20)18 e governando o Brasil nesse período, o bolsonarismo ai foi o salvo-conduto. Aquilo que o Temer preparou com a desregulamentação, o bolsonarismo liberou como caldo social. O Temer deu o marco legal, e o bolsonarismo deu o caldo cultural e político de dizer: “Tá permitido. Carta Branca. 


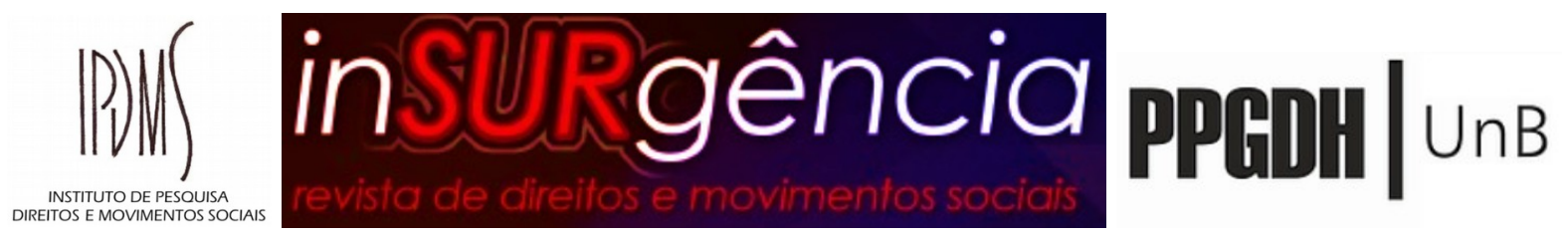

Pode invadir terra indígena. Mete mineração lá. Amplia a fronteira agrícola mesmo. Mete fogo nessa Amazônia toda, que isso não presta para nada, é coisa dos verdinhos. Vai lá e cai pra cima”. E o que a gente vê, naquilo que a Ermínia (Maricato) costuma dizer sempre da lei que pega e da lei que não pega no Brasil. O que a gente vê, é que justamente aquilo que foi apontado que seria um efeito positivo da lei de regulação fundiária, que era permitir regulação de bairros populares e favelas não tá acontecendo. A lei de regulação fundiária não está sendo aplicada e utilizada em larga escala pra isso no Brasil, apenas de forma muito pontual.

Henrique Frota, João Bazolli, André Arruda - Aproveitando a questão da Amazônia legal, e até pra interiorizar a questão, nós já temos um contexto de Haussmann na implantação da cidade de Palmas (TO), que já nasce higienizada. Então, uma estruturação, e a questão até do MCMV que você pontuou, no interior a renda da terra é absurda, porque na verdade ela vai pro rural. Avança absurdamente pro rural, e isso tem um contexto muito diferente das grandes capitais, né! Assim, dentro deste processo de interiorização, gostaríamos que você nos passasse, pra que conseguíssemos entender um pouco este cenário. E se você tem alguma radiografia do diálogo dos movimentos, porque a repressão é diferente daqui, com a repressão de São Paulo. Aqui, inclusive, quem faz a repressão é o cara que tá no mercado, o cara que tá no contexto do dia-a-dia. Então, as vezes o cara, quem vai fazer a repressão, é o cara que você conhece, né! Então, há uma articulação, dentro desse contexto dos movimentos? Qual é o ensaio? Qual a direção? Se há um contexto mais de fortalecimento dos movimentos? Porque a gente vê acontecer uma cooptação mesmo, efetiva de grupos. Mas, sem deixar em um contexto local especificamente, mas dentro desse contexto mais geral do Brasil, que o que você falou, a gente tem realidades diferentes, e a gente centraliza muito no Sul e no Sudeste, e os direcionamentos são voltados mais pro Sul e pro Sudeste. Então, em relação a este contexto, movimentação política, diálogo. Como que tá acontecendo isso? Percebemos até uma união das esquerdas, que você deve estar acompanhando aí. Queríamos que você nos passasse um pouco, pra que a gente consiga entender um pouco este contexto.

Guilherme Boulos - Vê só. É natural que de 2018 pra cá tenha tido um refluxo, uma certa desorganização do movimento social brasileiro, porque nós sofremos uma derrota muito forte. Nós não podemos minimizar o impacto, tanto da derrota do golpe de 2016, e a derrota eleitoral de 2018. Ela não é uma derrota eleitoral simplesmente, ela foi uma derrota histórica. 


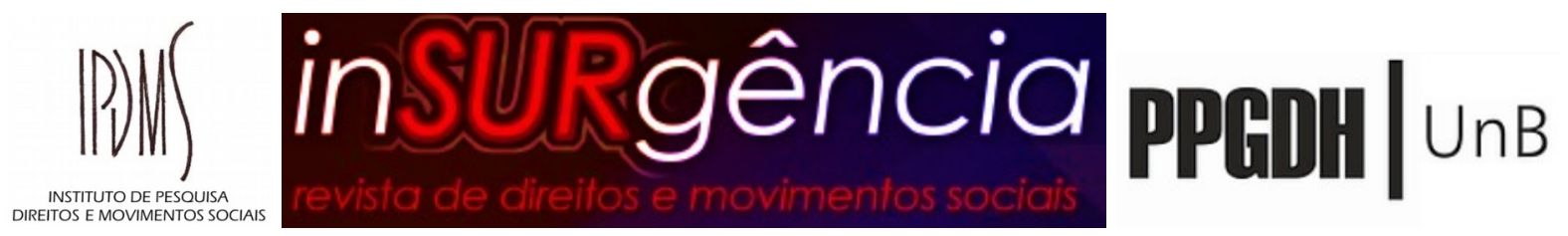

O Bolsonaro assumiu o governo do Brasil, né! A coisa mais direitista, mais atrasada, mais antidemocrática, que existia no espetro político brasileiro, ganhou uma eleição e também ganhou capilarização em governos estaduais, nos parlamentos estaduais e no parlamento federal. Isso gerou, num primeiro momento, um choque, e uma desarticulação. Como em toda derrota, não é? Em toda derrota, o exército derrotado, pra poder se reorganizar, precisa de tempo. Então, o que a gente viveu no último ano e meio, foi a esquerda tentando sair ali da lona, os movimentos sociais tentando sair ali da lona, e apontar uma perspectiva de resistência. Não tem sido fácil, mas eu vejo dois fatores importantes que apontam pra que o próximo período seja um período de amplificação das resistências sociais e políticas no Brasil. O primeiro é o fato do declínio do bolsonarismo. Bolsonarismo, há um ano e meio ganhou as eleições com 57 milhões de votos. No dia $1^{\circ}$ de janeiro de 2019, tinha uma expectativa positiva de $60 \%$ da população brasileira, e hoje o bolsonarismo, um ano e meio depois, tá cada vez mais enrolado, com 30\% de apoio como teto, inclusive com defecções políticas no seu próprio campo, sob um cerco judicial. Nós estamos hoje aqui conversando e o (Fabrício) Queiroz foi preso. O bolsonarismo tá começando a entrar na lona. Eles não estão derrotados, mas eles estão num momento muito difícil, mais difícil desde que assumiram o governo, não é? Pra poder se segurar ali, e evitar a abertura de um processo de impeachment, porque ele não tem mais força social pra sustentar isso. E as manifestações dos últimos finais de semana mostraram isso inequivocamente. Quando a esquerda resolveu ir pra rua, ainda que limitadamente, por a gente estar no meio de uma pandemia, nós fomos cinco, dez vezes mais, em número de pessoas, do que o bolsonarismo foi capaz de levar às ruas hoje. Eles estão se reduzindo cada vez mais a grupos alucinados, e perdendo o afã, a capacidade de mobilização. Tudo isso aponta pra uma reversão, ou pra pelo menos a abertura de pelo menos um outro caldo político para o próximo período.

E o segundo fator é o fator econômico. Vejam vocês, nós estamos no meio da crise sanitária. Vamos olhar os números. A crise sanitária vai passar, ela já tem passado, tem sido controlada, apesar da falta de estratégia e do genocídio que foi praticado aqui no Brasil, que tá sendo praticado, ela vai passar, ela vai estar controlada dentro de alguns meses. O que vai ficar no pós crise sanitária? Vai ficar um rastro de crise econômica sem precedentes na história brasileira. A comparação possível é só com (19)29, e vamos lembrar que a crise de (19)29 derrubou a República Velha, acabou com a economia cafeeira, gerou a revolução de (19)30, e um outro modelo do Brasil. A crise mais próxima dessa nossa geração, comparável a que nós 


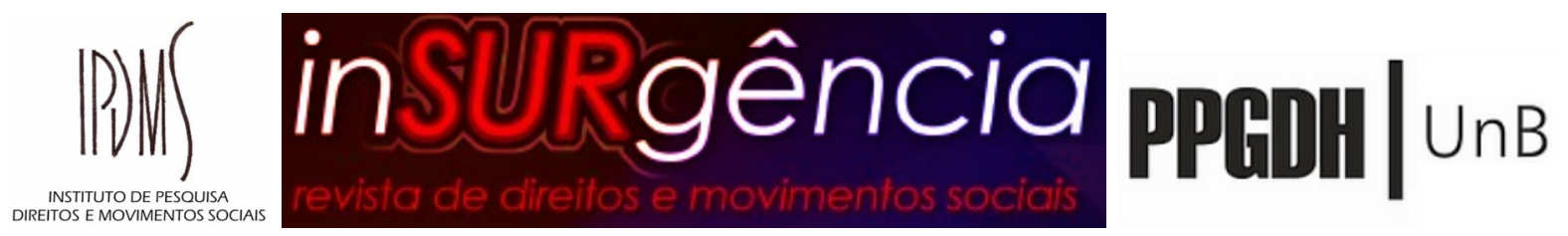

vamos viver com mais intensidade a partir de agora não foi nem a de 2008, foi a dos anos (19)80, com a crise do petróleo e a crise da dívida. Quando chegou a ter saque nas grandes cidades, quando chegou a ter um nível de miséria tremendo no Brasil. Essa crise, do ponto de vista numérico é muito maior que a dos (anos) (19)80. Nós estamos falando do Brasil poder pular de 13 milhões de desempregados, pra 25 milhões de desempregados em poucos meses. A quantidade de seguro desemprego pedida no último trimestre é recorde da história. Nós estamos falando de uma falência em série de comércio, pequena empresa, microempresa e média-empresa. Nós estamos falando, hoje, de 40 milhões de trabalhadores na informalidade virarem 60 (milhões). Estamos falando da desagregação do tecido social e econômico do país. Ou seja, o cenário que tá colocado é gravíssimo. Todas as vezes que você teve uma crise econômica parecida com essa, estou nem falando dessa, se derrubou o governo. Caiu o governo. Nos anos (19)30 caiu a República Velha, nos anos (19)80 caiu a ditadura, não é? Na crise do início dos anos (19)90 caiu o Collor, e nos rescaldos da crise de 2008 caiu a Dilma. Então, a situação econômica com Bolsonaro é muito difícil, ele tenta controlar a narrativa e jogar a culpa da crise na esquerda, nos comunistas, no PT, nos governadores, "porque fizeram isolamento, porque defenderam isolamento, e foi isso que emperrou a economia”. Ele vai tentar controlar a narrativa. Mas narrativa não enche a barriga de ninguém. $\mathrm{O}$ fato objetivo é que o povo tá ferrado e que vai ser difícil o governo se sustentar. E o ponto final significa também o movimento social ascendente. Já começou a acontecer aqui em São Paulo, com ocupações espontâneas nos quatro cantos da cidade, no meio da epidemia, porque as pessoas não conseguem mais pagar aluguel, porque as pessoas tão desempregadas. Isso sem qualquer iniciativa do movimento social, que tá tendo os cuidados de não agir, não fazer grandes ações durante a pandemia. Mas tá acontecendo, e vai acontecer muito mais quando a pandemia passar no Brasil inteiro. Aí eu acho que nós vamos ter um desafio de rearticular estas ações em âmbito nacional. Nós vamos ter um desafio de construir um guarda-chuva de movimento social que seja capaz de dar a direção pra isso, dar um rumo pra isso. Acho que esse vai ser o desafio do período, que pode mudar completamente a correlação de forças no Brasil em questão de meses, ou de um ou dois anos.

Henrique Frota, João Bazolli, André Arruda - Muito bem. Teríamos somente uma última pergunta, já que estamos chegando ao fim da nossa entrevista. Diante desse contexto que nós estamos lutando, em nosso entendimento, contra coisas assim, mínimas da sobrevivência, da 


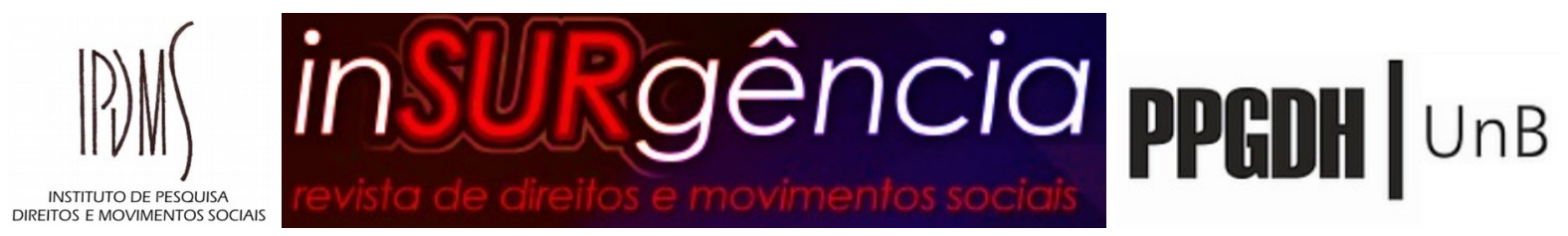

nossa sobrevivência enquanto sociedade. Estamos lutando pela democracia, lutando contra o fascismo, lutando contra o racismo. Entretanto, esse ano é um ano, também na agenda política, importante, em virtude das eleições municipais. Quer dizer, o Direito à Cidade, de alguma maneira, vai se colocar. Mas você acha que, diante deste contexto, que é tão dramático, de desemprego, de racismo, de tudo que a gente tá discutindo aqui, a pauta urbana, a pauta fundiária, a pauta habitacional, ela vai ter alguma relevância, no seu entendimento esse ano? Ou a gente vai continuar tendo que enfrentar as ameaças contra a democracia? Enfrentamentos super profundos e importantes que estão sendo feitos. Pra junto disso, haverá ou não uma rediscussão do que é o Direito à Cidade?

Guilherme Boulos - Bom, eu acho assim, nós estamos no meio de uma crise democrática e claro que isso vai pautar o debate nacional. Essas eleições municipais vão ser muito nacionalizadas, polarizadas com bolsonarismo e antibolsonarismo. É inevitável. Agora eu acho que justamente pela pandemia, o tema da moradia, e o tema do direito à cidade estarão no centro da agenda nacional. Vou te dizer por que: porque nunca o tema sobre condições de moradia para o povo esteve tão em voga quanto num período em que o mundo todo diz: “fique em casa”. Essa foi a palavra de ordem dos últimos três meses no mundo, quatro meses no mundo. Aí vem a segunda questão: “que casa?”. Como que você vai dizer “fique em casa” para alguém em situação de rua? Como é que você vai dizer “fique em casa” para o cara que mora num barraco de 3x4 com outras 4 pessoas? Como é que se vai dizer para ele se isolar nestas circunstâncias? “Lave a mão toda hora!” Como é que se vai dizer pra lavar a mão em um bairro que não chega água, e onde o saneamento básico é precário? Então, aquilo que eram problemas invisíveis, porque não chegavam ao grande público, porque não afetam a classe média urbana. E os problemas que são considerados públicos nas cidades brasileiras, são problemas que afetam a classe média urbana. A mobilidade é um problema público. O urbanismo é um problema público. As áreas verdes, a poluição são problemas públicos. É evidente que é um problema público, mas a moradia também é, e não é tratada assim. $\mathrm{O}$ saneamento básico também é, e não é tratado assim. Estavam invisibilizados, porque são problemas que afetam setores populares, tão somente. Então agora, acho que nunca se lançou tanta luz sobre estes temas como nos últimos meses. É inevitável que isso traga um aprendizado para as eleições municipais. A população em situação de rua, tenho visto e ouvido relatos, e estou escrevendo sobre isso, e pra isso fui ler muitas coisas do mundo todo. 


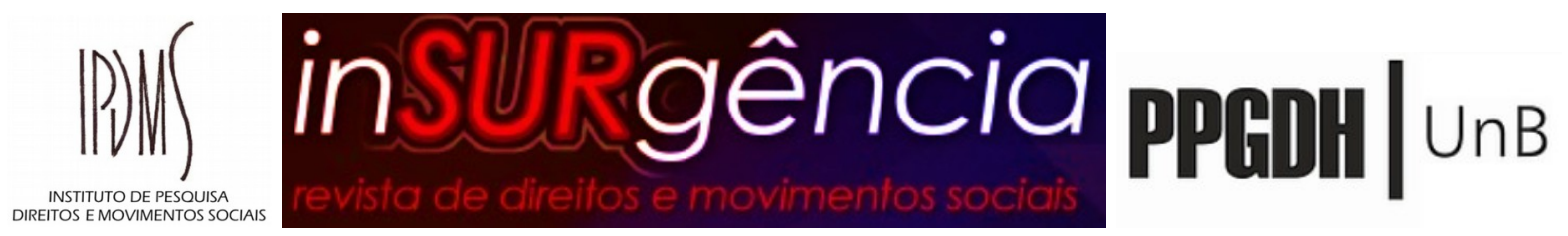

Vi gente da Inglaterra que trabalha há décadas com população em situação de rua dizendo: "nunca chegou tanta ajuda! Nunca veio tanta gente falar do tema! Nunca tantos pesquisadores ou tantos jornalistas os procuraram!”. Teve-se uma visibilização de temas invisíveis e de pessoas invisíveis, que nós precisamos trabalhar para que continue na agenda depois que a pandemia passar. Esse eu acho que vai ser o desafio da eleição municipal. E aqui, nós estamos falando de condições de moradia, estamos falando de sem-teto, estamos falando de saneamento básico, estamos falando, em suma, de direito à cidade. Então, eu acho essencial que essa pauta tenha uma centralidade. Eu consolidando a pré-candidatura aqui em São Paulo, vai ser uma linha de campanha nossa central. Tratar esses temas, o tema da moradia, o tema do direito à cidade, trazer pro centro do debate, porque eu acho que nós temos uma oportunidade histórica. Acho que o clima e o debate que a pandemia abriu dá uma oportunidade histórica pra gente tratar disso.

Henrique Frota, João Bazolli, André Arruda - Bom Guilherme, estamos chegando já no nosso limite. A entrevista virou uma aula. Queríamos muito te agradecer. Foi fantástico. E temos certeza que, da parte do IPDMS, há um agradecimento muito especial pela sua generosidade no tempo, e de dividir conosco seu conhecimento. E queríamos te dizer que seguimos juntos. Destacando que isto vai trazer um folego pros pesquisadores $e$ pesquisadoras, pros movimentos sociais que constroem conosco o IPDMS. Então essa sua generosidade é sem fim, e traz sim uma centralidade pra gente se organizar e pra agir neste próximo período. Te agradecemos muito em nome do IPDMS.

Guilherme Boulos - Muito bom. Queria agradecer a vocês pelo bate-papo. Gostei bastante também, e estou à disposição. De fato o tempo tá corrido. É incrível, como, no período em que parou tudo, a gente tá com o tempo como opressor, reunião às 23 horas por vídeochamada. É um negócio impressionante, a gente vai de um lugar pro outro. Mas foi muito legal este bate-papo. Muita sorte para vocês na revista. E, “tamo junto!”.

Submetido em 30/07/2020.

Aprovado em 31/07/2020. 